\title{
Model Pengelolaan Perikanan Tangkap \\ Berbasis Kawasan Konservasi Perairan (KKP) \\ Untuk Meningkatkan Hasil Tangkapan Nelayan - Suatu \\ Pendekatan Teoritis
}

\author{
Didik Santoso ${ }^{1}$ \\ ${ }^{1}$ Program studi pendidikan biologi FKIP Universitas Mataram \\ Email : didik.santoso@gmail.com
}

\begin{abstract}
Abstrak
Kawasan Konservasi Perairan (KKP) atau Marine Protected Area (MPA) merupakan suatu kawasan di wilayah perairan laut yang dilindungi secara hukum atau cara lain yang efektif. Kementrian Kelautan dan Perikanan (KKP) bertujuan untuk mengusahakan terwujudnya kelestarian sumber daya alam dan keseimbangan ekosistemnya, sehingga mendukung upaya peningkatan kesejahteraan masyarakat serta mutu kehidupan manusia. Terdapat bukti yang kuat dan meyakinkan bahwa melindungi daerah dari penangkapan ikan membuat bertambahnya jumlah, besarnya ukuran, dan biomasa dari jenis organisme yang dieksploitasi.
\end{abstract}

Kata kunci : kawasan konservasi perairan, marine protected area.

\begin{abstract}
Marine Protected Area (KKP) is an area in the sea waters which is legally protected or otherwise effective. Ministry of Marine Affairs and Fisheries (KKP) aims to strive for the realization of natural resources and balance of ecosystems, thus supporting efforts to improve the welfare of society and the quality of human life. There is convincing evidence that protecting the area from catching fish increases the number, size, and biomass of the type of exploited organism.
\end{abstract}

Key Word : Marine Protected Area (MPA), Ministry of Marine Affairs and Fisheries (KKP) 


\section{Pendahuluan}

Kawasan Konservasi Perairan (KKP) atau Marine Protected Area (MPA) adalah wilayah perairan laut termasuk pesisir dan pulau-pulau kecil yang mencakup tumbuhan dan hewan didalamnya, serta/atau termasuk bukti peninggalan sejarah dan sosial-budaya dibawahnya, yang dilindungi secara hukum atau cara lain yang efektif, baik dengan melindungi seluruh atau sebagian wilayah tersebut. KKP meliputi : Kawasan Konservasi Laut Daerah (KKLD), Taman Nasional Laut (TNL), Taman Wisata Alam Laut (TWAL), Cagar Alam Laut (CAL), Suaka Margasatwa Laut (SML), Daerah Perlindungan Laut (DPL)/ Daerah Perlindungan Mangrove (DPM), Suaka Perikanan (SP) (CORMAP).

Tujuan melakukan konservasi tersebut adalah untuk mengusahakan terwujudnya kelestarian sumber daya alam dan keseimbangan ekosistemnya, sehingga dapat lebih mendukung upaya peningkatan kesejahteraan masyarakat serta mutu kehidupan manusia (Dirjen P3K, 2004). Strategi yang digunakan untuk mewujudkan tujuan tersebut adalah dengan tiga $\mathrm{P}(3 \mathrm{P})$, yaitu: a. Perlindungan sistem penyangga kehidupan; $b$. Pengawetan keanekaragaman jenis tumbuhan dan satwa liar beserta ekosistemnya; c. Pemanfaatan secara lestari sumber daya alam hayati dan ekosistemnya.

Proses perlindungan, pengawetan dapat dilakukan di kawasan konservasi, taman hutan raya, dan taman wisata alam; mengingat kawasan konservasi itu adalah kawasan pelestarian alam yang mempunyai ekosistem asli, dikelola dengan sistem zonasi yang dimanfaatkan untuk tujuan penelitian, ilmu pengetahuan, pendidikan, menunjang budidaya, pariwisata, dan rekreasi (Dirjen P3K, 2004). Dari ketiga strategi tersebut satu dengan lainnya sangat berkait, sehingga untuk mewujudkan kelestarian sumber daya alam hayati dan ekosistemnya harus dilakukan bersamasama. Artinya kalau yang dilakukan hanya satu aspek, misalnya perlindungan saja tanpa dibarengi dengan pengawetan dan pemanfaatan, maka akan menimbulkan resiko biaya pengelolaan yang sangat tinggi, dengan tanpa memperoleh hasil. Sebaliknya, jika kegiatan tersebut hanya memfokuskan pada aspek pemanfaatan dengan tanpa memperhatikan pada perlindungan dan pengawetan, maka yang akan terjadi tentu saja pemusnahan sumber daya alam hayati tersebut (Nurhadi, 2001).

Berdasarkan bukti-bukti dari penutupan wilayah laut terbatas yang ada, baik di daerah tropis maupun sub-tropis, kawasan konservasi laut dan laut lindung bisa digunakan sebagai alat yang efektif untuk mengungkapkan kebutuhan konservasi sebagai bagian dari pengelolaan wilayah pesisir dan lautan secara terpadu. Di seluruh dunia, luasan daerah perairan laut dilindungi sangat kecil. Saat ini seluruh wilayah KKP hanya meliputi kurang dari setengah persen lautan di dunia, sedikit yang sangat dilindungi dan $71 \%$ tidak ada pengelolaan yang aktif.

Terdapat bukti yang kuat dan meyakinkan bahwa melindungi daerah dari penangkapan ikan membuat bertambahnya jumlah, besarnya ukuran, dan biomasa dari jenis organisme yang 
dieksploitasi. Wilayah penyimpanan dan perlindungan laut sering dikatakan hanya berlaku untuk lingkungan terumbu karang. kenyataannya, metode ini sudah berhasil diterapkan pada berbagai habitat di dalam lingkungan dari kondisi tropis maupun sub-tropis. Penyimpanan dan perlindungan laut adalah suatu alat yang bersifat global.

Penangkapan berlebih atau 'overfishing' sudah menjadi kenyataan pada berbagai perikanan tangkap di dunia Organisasi Pangan dan Pertanian Dunia (FAO) memperkirakan $47 \%$ dari perikanan laut dunia sudah tereksploitasi penuh (fully exploited), $18 \%$ mengalami tangkap lebih atau stok yang tersisa bahkan sudah terkuras - hanya $10 \%$ dari sumberdaya masih berada pada kondisi tangkap kurang (FAO, 2002). Total produksi perikanan tangkap dunia pada tahun 2000 ternyata 5\% lebih rendah dibanding puncak produksi pada tahun 1995 (tidak termasuk Cina, karena unsur ketidak-pastian dalam statistik perikanan mereka). Sekali terjadi sumberdaya sudah menipis, maka stok ikan membutuhkan waktu yang cukup lama untuk pulih kembali, walaupun telah dilakukan penghentian penangkapan.

Hasil penelitian terakhir mendapatkan bahwa banyak stok ikan sudah mengalami penurunan secara terus menerus sejak pertama kali ditangkap, dan populasi ikan (tuna, marlin, ikan cod, dan lain-lain) berkurang 80\% dalam 15 tahun sejak pertama kali dieksploitasi (Myers \& Worm, 2003).Hal ini juga dirasakan di Indonesia, produksi perikanan menunjukkan tren yang menurun hal ini ditunjukkan dengan semakin sedikitnya ikan yang tertangkap dan semakin menurunnya ukuran ikan yang tertangkap. Untuk itu perlu segera dilakukan upaya untuk memperbaiki kondisi daerah penangkapan ikan (DPI) agar nelayan dapat meningkatkan produksi perikanan mereka.

\section{Model Pengelolaan Perikanan Tangkap Berbasis Konservasi Perairan}

Agar kawasan konservasi laut ini dapat efektif dan dapat dirasakan langsung oleh masyarakat kususnya masyarakat di wiliayah pesisir maka penentuan lokasinya haruslah melibatkan masyarakat sebagai pengguna wilayah, dengan mengikuti langkah berikut. Pertama, metode Focused Group Discussion (FGD) digunakan untuk mengumpulkan informasi keberadaan sumberdaya wilayah pesisir yang akan dijadikan calon kawasan konservasi dengan melibatkan pengguna sumberdaya seperti nelayan, pedagang ikan, pembudidaya, pengusaha, dan pemerintah. Pada kegiatan ini dibahas pula aturan pengelolaan yang disepakati. Kedua bersama dengan wakil masyarakat yang ditunjuk melakukan penilaian kondisi habitat dari kawasan konservasi yang disepakati. Hal ini dilakukan sebagai dasar untuk menentukan zonazona dalam kawasan konservasi tersebut terutama zona inti yang merupakan zona larang ambil (no take zone area). Zona larang ambil ini harus dipilih dengan kondisi habitat yang baik. Ketiga sosialisasi tentang pentingnya kawasan konservasi dengan menggunakan media koran (lokal), pamflet, poster, dan sosialisasi di sekolah dan guru. Keempat sosialisasi keberadaan calon lokasi kawasan konservasi yang telah disepakati melalui media koran (lokal), pamflet, poster, dan sosialisasi di sekolah dan guru. Kelima pemberian tanda batas- 
batas geografis KKP (zona inti, zona penyangga, dan zona pemanfaatan). Terakhir konsultasi publik, kegiatan ini dimaksudkan untuk mendapatkan legitimasi kawasan konservasi yang telah disepakati dari masyarakat yang luas.
Legitimasi ini berupa penandatanganan dokumen KKP beserta dengan aturan pengelolaannya oleh wakil-wakil masyarakat seperti Kepala Desa, Badan Musyawarah Desa, dengan mengetahui wakil dari pemerintah.

Model pengelolaan perikanan tangkap berbasis Kawasan Konservasi Perairan (KKP) tersebut seperti pada gambar 1.

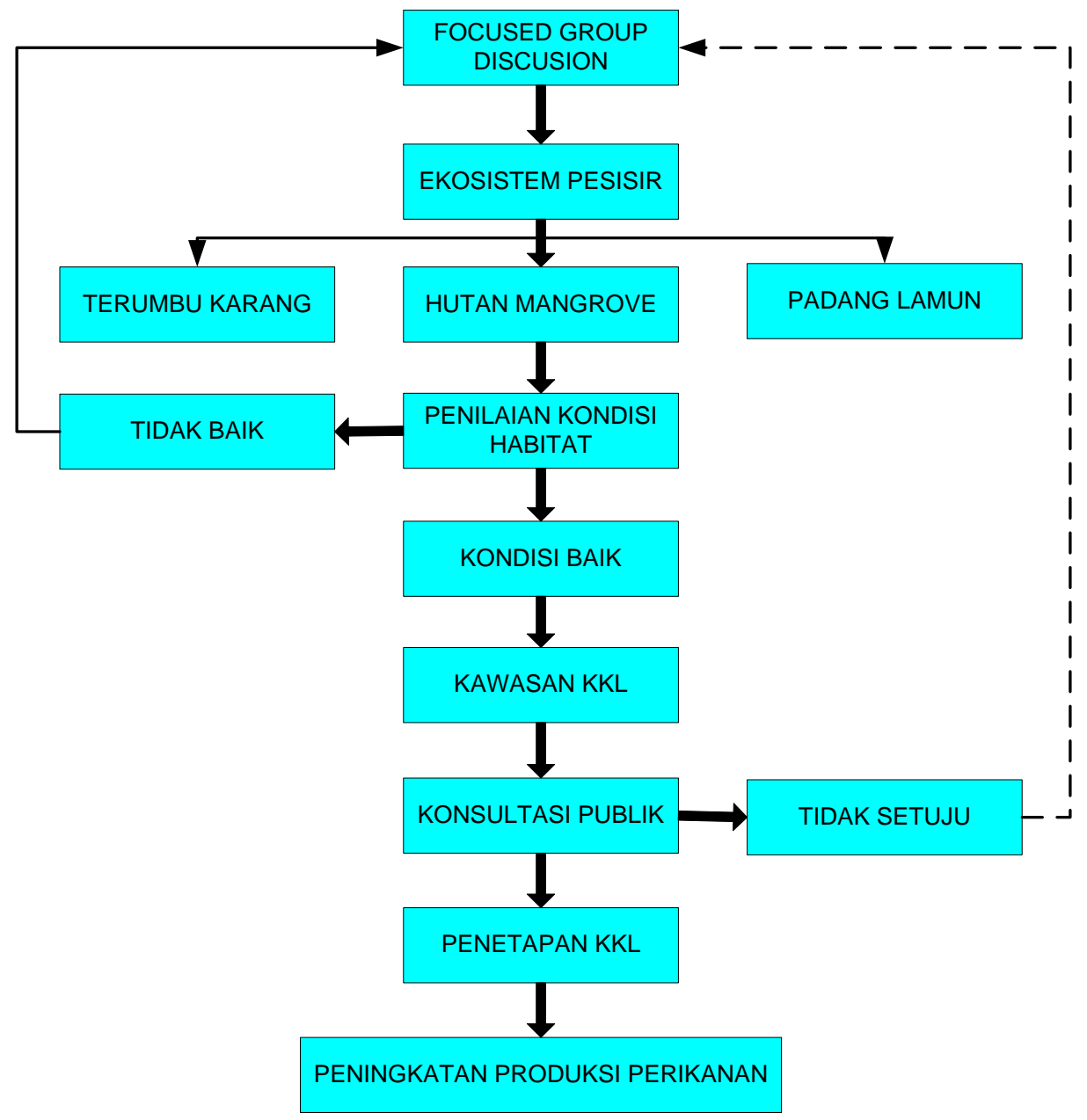

Gambar 1. Model pengelolaan perikanan tangkap berbasis Kawasan Konservasi Laut (KKP)

\section{Penilaian HabitatTerumbu Karang.}

Ada 2 penilaian kondisi terumbu karang yang utama, yaitu ikan karang dan life form karang. Pengamatan kedua komponen ini biasanya dilakukan oleh dua tim yang berbeda yaitu tim yang mengamati komponen ikan dan life form
karang.Pengamatan variabel jenis dan kelimpahan ikan dilakukan pada lokasi yang sama dengan lokasi pengamatan variabel lifeform karang. Sebelum pengamatan dilakukan terbebih dahulu dibuat transek pada kedalaman \pm 10 meter sejajar kontur dasar perairan dengan cara 
membentangkan roll meter di atas permukaan substrat. Setelah itu ditinggalkan beberapa saat untuk memberikan kesempatan kepada obyek yang akan diamati yaitu ikan karang kembali ke posisi semula yang mungkin tergangggu pada saat pemasangan transek.

Lifeform karang yang diamati ditentukan berdasarkan kategori yang tercantum dalam Survey Manual For tropical Marine Resources (English et al., 1994) dengan metode transek garis (line transect). Setiap jenis substrat (life form karang) yang berada di bawah garis transek dicatat dengan ketelitian 1 cm.Analisis terhadap persentase penutupan setiap kategori untuk pertumbuhan (life form) karang ditentukan derngan rumus (English et al., 1994) :

$$
\text { Persentase }=\quad \frac{\text { Panjang Total Kategori }}{\text { Panjang Transek }} \times 100 \%
$$

Komponen-komponen bentuk komunitas ikan, sementara anggota tim pertumbuhan (life form) dikelompokkan menjadi 5 kelompok, yaitu : karang batu hidup (hard coral, HC), alga (algae, AL), organisme lain (others, OT), karang mati (dead coral, DC), dan abiotok (abiotic, $\mathrm{AB})$.

\section{Komunitas Ikan Karang, Mangrove, dan Padang Lamun}

Untuk pengamatan terhadap komunitas ikan karang yang dilakukan dengan cara sensus visual (visual census method) sebagaimana yang disarankan oleh English et al., (1994). Dalam setiap kegiatan pengamatan, anggota tim terdiri dari dua orang. Pada saat pengamatan dilakukan, salah seorang dari tim yang lainnya sebagai mitra selam (buddy) mencatat keadaan umum daerah yang diamati. Variabel yang diamati adalah komposisi spesies ikan karang yang ditemukan sepanjang garis transek dengan radius 2,5 meter ke arah kiri dan kanan garis transek.

melakukan sensus visual terhadap

Pengamatan mangrove dapat dilakukan dengan cara analisis vegetasi (anveg). Anveg dilakukan dengan teknik gabungan yaitu transek garis sepanjang $100 \mathrm{~m}$ dan kuadrat dengan luas $10 \times 10$ $\mathrm{m}$, dimana kuadrat diletakkan diantara garis transek dengan jarak antar kuadrat adalah sepanjang $10 \mathrm{~m}$. Sementara untuk lamun kuadrat seluas $1 \times 1 \mathrm{~m}$ dengan jarak yang sama.

Analisis data dari semua variabel diatas dilakukan dengan indeks keanekaragaman Shannon-Wienner (H') yang dihitung dengan rumus menurut Magurran (1988) :

$$
\mathrm{H}^{\prime}=\quad-\sum \text { pi ln pi }
$$

Dimana :

H' = Indeks Keanekaragaman Shannon

pi $=$ Proporsi spesies ke i terhadap individu seluruh spesies $(\mathrm{ni} / \mathrm{N})$. 
Indeks keseragaman (Evennes, E) dihitung dengan membandingkan antara keanekaragaman dengan keanekaragaman maksimal, dengan rumus Magurran (1988):

Dimana :

$$
\mathrm{E}=\mathrm{H}^{\prime} / \mathrm{Hmaks}
$$

$\mathrm{E}=$ Indeks Keseragaman (Evennes)

Hmaks $=\ln \mathrm{S}$

$\mathrm{S}=$ Jumlah jenis

Nilai $\mathrm{E}$ berkisar antara 0 sampai dengan 1. jika $E=1$ berarti semua spesies memiliki kelimpahan yang sama.

Untuk menentukan adanya dominasi dalam ekosistem tersebut digunakan indeks Simpson (D) Magurran(1988) sebagai berikut :

Dimana :

$$
\mathrm{D}=\sum(\mathrm{pi})^{2}
$$

D = Indeks Dominansi Simpson

$\mathrm{Pi}=$ Proporsi spesies ke $\mathrm{i}$ terhadap total individu seluruh spesies $(\mathrm{ni} / \mathrm{N})$.

Luas yang optimal untuk KKP adalah antara 15-25\% (dari daerah tangkapan ikan) jika intensitas perikanan di daerah sekitarnya tidak melebihi $40 \%$ dari total biomass yang bisa dieksploitasi (Rodwell L.D., at al. 2001).

\section{Kawasan Konservasi Laut Dan Manfaatnya Bagi Peningkatan Produksi Perikanan}

Secara geografis, Indonesia berada di antara 2 benua, 2 samudera dan tempat pertemuan lempengan benua, menjadikan posisi Indonesia sangat strategis. Tak pelak lagi, kurang lebih 95 $\%$ jalur pelayaran perdagangan Asia Pasifik melewati perairan kita.

Angka panjang pantai yang cukup fantastik, $95.181 \mathrm{~km}$, menempati posisi ke_4 setelah Canada, Amerika dan Rusia, menawarkan beragam keindahan pantai yang bernilai jual tinggi untuk kegiatan pariwisata dan olah raga kebaharian. Bali, Lombok, Manado, Pulau Derawan, Gugus kepulauan Wakatobi, Raja Ampat merupakan nama-nama yang tidak asing lagi bagi wisatawan domestik maupun manca negara dan selalu berada dalam katalog tour agent di seluruh dunia.

Namun demikian luasnya perairan laut tidak diimbangi dengan produk yang dihasilkan. Menurut Menteri Kelautan dan Perikanan, sumbangan sektor perikanan (di Indonesia) terhadap PDB hanya sekitar $2 \%$. Hal ini sangat jauh berbeda jika dibandingkan dengan negara-negara lain misalnya Korea Selatan, Jepang, dan Thailan. Walaupun total garis pantai di Korea Selatan dan Jepang hanya $2.731 \mathrm{~km}$ dan $34.386 \mathrm{~km}$, sumbangan sektor perikanannya mencapai 37\% dan 54\% dari PDB. Sama halnya dengan di Thailand, yang hanya memiliki garis pantai sepanjang 2.600 $\mathrm{km}$, per tahunnya mampu meraup devisa lebih dari US\$ 5 miliar dari ekspor ikan. Dari alasan yang sangat jelas ini, Pemerintah Indonesia telah memutuskan untuk memulai Program Pengelolaan Perikanan yang terpadu untuk mengoptimalkan penggunaan sumberdaya perikanan secara 
bekelanjutan. Pada skema ini devisa dari ekspor perikanan ditargetkan mencapai US\$ 5 miliar dan sumbangan sektor perikanan terhadap PDB diharapkan mencapai 5\%. Salah satu kendala utama untuk mencapai tujuan di atas adalah fakta bahwa nelayan di Indonesia umumnya adalah nelayan kecil dengan ciri khas skala usaha kecil, modal terbatas dan padat tenaga kerja.

Intensitas pembangunan yang tinggi, ternyata memberikan dampak dan tekanan yang besar terhadap kelestarian sumber daya pesisir dan laut. Kegiatan perikanan destruktif seperti penggunaan bahan peledak, racun sianida, penambangan karang, dan penebangan mangrove untuk pengalihan lahan pesisir merusak ekosistem pesisir dan laut, seperti ekosistem mangrove dan terumbu karang.

Salah satu upaya penting yang mulai banyak diterapkan dalam mengurangi dampak degradasi sumberdaya kelautan adalah pengembangan program konservasi laut melalui pembentukan dan pengelolaan Kawasan Konservasi Laut. Langkah ini dipandang sebagai cara paling efektif untuk melindungi keanekaragaman hayati laut beserta nilai ekonomi yang terkandung didalamnya.

Kawasan Konservasi Perairan (KKP) dibentuk dalam suatu wilayah pesisir dan laut dengan batas geografis yang tegas dan jelas, ditetapkan untuk dilindungi melalui perangkat hukum atau aturan mengikat lainnya, dengan tujuan konservasi sumberdaya hayati dan kegiatan perikanan yang berkelanjutan di sekitar (luar) wilayah KKP. Secara hakiki, maksud ditetapkannya KKP adalah untuk dapat melestarikan fungsi dan pelayanan dari ekosistem (ecosystem services) tersebut bagi keseimbangan ekologis dan kesejahteraan manusia.

Telah banyak bukti yang menunjukkan bahwa kawasan konservasi laut dapat dengan cepat mengembalikan fungsi suatu ekosistem pesisir bukan hanya sebagai daerah perlindungan dari berbagai macam biota laut tapi juga dapat dengan cepat meningkatkan hasil tangkapan nelayan. Australia misalnya suatu jaringan interaksi yang tersusun atas 5 unit KKP kecil di St. Lucia, setelah 5 (lima) tahun dari pembentukannya, dapat meningkatkan hasil tangkapan nelayan kecil di sekitarnya antara 46\% 90\%. Di Florida, kawasan konservasi Merritt Island National Wildlife Refuge telah menyumbang pertambahan jumlah ikan-ikan yang berukuran besar (rekor dunia) terhadap kegiatan perikanan rekreasional di sekitarnya sejak 1970-an (Roberts C.M., at all, 2001).

Untuk mengembalikan populasi ikan dan melindungi ekosistem, pengelola perikanan harus membuat kebijakan yang tujuannya diarahkan untuk mengurangi penangkapan secara substansial, menurut Perikanan Laut yang Berkelanjutan dalam sebuah laporan yang dibuat oleh panitia dari National Research Council. Di dalam rencana pengelolaan seharusnya tidak hanya perikanan yang bersifat komersial tetapi juga untuk perikanan rekreasional dan subsisten. Luas wilayah pesisir dan laut yang dilindungi harus ditingkatkan, dimana wilayah tertutup tersebut tidak diijinkan untuk melakukan penangkapan ikan. Sebagai tambahan, pengelola harus melakukan tindakan seperti pemberian hak ulayat penangkapan ikan yang eksklusif kepada masyarakat atau perorangan sehingga tidak terjadi penangkapan berlebih (The National 
Academies,

http://www4.nas.edu/news.nsf/isbn/03090

55261? Download, 29 Nopember 2007).

KKP menjadi sangat efektif jika

dibuat di tempat yang terbuka dimana spesies tinggal, berkembang-biak atau mencari makan. Pembuatan KKP akan secara cepat mengembalikan populasi ikan, siput, dan kepiting, serta menyediakan habitat bagi organisme laut lainnya di daerah yang sama. Untuk menjamin adanya manfaat yang sangat besar bagi stok ikan yang sudah mengalami tekanan penangkapan berlebihan, jumlah daerah yang dilindungi harus diperbanyak, selain yang sudah aktif, menjadi daerah perikanan yang produktif. Lebih jauh lagi, nelayan harus dilibatkan dalam perencanaan dan penentuan daerah yang dilindungi. Hal ini menjadi sangat penting, karena dengan keterlibatan masyarakat setempat akan menjamin keamanan dan kelestarian KKP yang telah ditetapkan.

Banyak ikan karang berkumpul di tempat-tempat tertentu untuk memijah. KKP dapat membantu melindungi tempat-tempat pemijahan ini, yang sangat rentan terhadap usaha penangkapan ikan baik secara tradisional maupun komersial keberadaan tempat-tempat pemijahan yang penting, dapat dijadikan sebagai alasan untuk menentukan lokasi KKP. Pada wilayah-wilayah KKP multi-guna yang luas dan besar, lokasi pemijahan bisa ditentukan sebagai wilayah terlarang untuk penangkapan (Johannes R.E. 1998).

Keuntungan ekonomis dari perlindungan tempat-tempat pemijahan ikan kerapu. Dampak dari perlindungan ini sangat jelas bagi pengelola. Pertama, KKP menyediakan alasan ekonomi bagi perlindungan secara tegas terhadap tempat yang diketahui dan potensial sebagai tempat-tempat pemijahan. Kedua, di Taman Nasional Komodo (TNK), tempat-tempat pemijahan tersebut secara nyata mempunyai nilai ekonomi yang setara dengan nilai rekreasi dari fungsi taman nasional secara keseluruhan. Terakhir, usaha-usaha perlindungan menyeluruh yang konsisten dengan melindungi daerah penangkapan ikanikan dasar, di mana sebagian besar rumah tangga tergantung pada wilayah di luar lokasi TNK (Ruitenbeek. 2001).

Dalam sebuah penelitian tentang spiny lobster (Udang Barong), hasil penelitian menunjukkan bahwa penolakan KKP oleh industri perikanan lobster pada asumsi menghilangnya jalur masuk ke daerah penangkapan secara spatial akan menurunkan rata-rata hasil tangkapan, ternyata tidak terbukti (Kelly S., at all. 2001).

KKP memberikan keuntungan yang nyata pada sektor pariwisata. Telah dibuktikan di beberapa tempat dimana terumbu karang sudah dilindungi dengan baik, termasuk pada beberapa lokasi sebagai berikut: Netherlands Antilles (Taman Nasional Laut Bonaire), dimana pariwisata selam meningkat; the Seychelles (Taman Nasional Laut Ste. Anne), dimana taman nasional digunakan baik oleh turis maupun penduduk setempat untuk berenang, berlayar, snorkeling, selam, dan perjalanan perahu beralas kaca (glass bottom boat); Fiji (Tai Island), dimana hasil tangkapan nelayan kecil meningkat, kegiatan pariwisata berkembang pesat, dan pemegang hak penangkapan tradisional (eksklusif) dilibatkan dalam pengelolaan resort dan penyewaan perahu; Cozumel Island (Mexican Caribbean) dimana terjadi peningkatan jumlah wisatawan lokal dan 
manca negara yang datang untuk menyaksikan melimpahnya ikan-ikan karang; dan Kenya (Taman Nasional dan Cagar Alam Malindi/Watamu), dimana pariwisata menghasilkan pendapatan melalui tiket masuk, biaya pemandu dan biaya kemping, penyewaan perahu dan peralatannya, serta hotel. Pada sisi lain, juga terjadi keuntungan tidak langsung dengan adanya permintaan terhadap lapangan pekerjaan di hotel-hotel, sebagai pemandu dan pengemudi perahu ( McNeely et all, 1994)

Jadi jelaslah dari berbagai KKP yang di contohkan di atas bahwa kawasan konservasi laut ini disamping mampu melindungi habitat ikan juga secara langsung dapat meningkatkan hasil tangkapan nelayan. Terlebih lagi nelayan di Indonesia yang sebahagian besar merupakan nelayan tradisional dengan wilayah penangkapan adalah di wilayah perairan pantai dengan mengandalakan ekosistem yang tersebar di wilayah pesisir.

Sampai dengan saat ini di daerah lain di NTB belum memiliki KKLD, termasuk Kabupaten Lombok Barat. Hal ini sangat berarti karena di Kabupaten ini banyak di temukan satwa liar langka, habitat ikan yang kritis, serta memiliki sebuah pulau yang termasuk sebagai salah satu pulau terluar sebagai titik pangkal batas wilayah Negara Kesatuan Republik Indonesia. Namun demikian pada tahun 2007 di Kabupaten Lombok Barat melalui Dinas Perikanan dan Kelautan Propinsi NTB telah dilakukan identifikasi Kawasan Konservasi Perairan. Dari hasil kegiatan tersebut telah teridentifikasi kawasan yang sangat sesuai untuk diusulkan sebagai calon KKLD yaitu kawasan pantai selatan
Kabupaten Lombok Barat yaitu di daerah Teluk Sepi, dan di Batu Kapal.

\section{Kesimpulan}

Dari uraian di atas dapat ditarik beerapa kesimpulan :

A. Kawasan Konservasi Perairan (KKP) atau Marine Protected Area (MPA) adalah wilayah perairan laut termasuk pesisir dan pulau-pulau kecil yang mencakup tumbuhan dan hewan didalamnya, serta/atau termasuk bukti peninggalan sejarah dan sosial-budaya dibawahnya, yang dilindungi secara hukum atau cara lain yang efektif, baik dengan melindungi seluruh atau sebagian wilayah tersebut.

B. KKP dimaksudkan untuk melindungi habitat ikan, larvae, anakan, serta induk ikan dari upaya penangkapan.

C. Pembuatan KKP akan secara cepat mengembalikan populasi ikan, siput, dan kepiting, serta menyediakan habitat bagi organisme laut lainnya di daerah yang sama.

D. Di sektor pariwisata KKP terbukti mampu menarik wisatawan untuk datang ke wilayah konservasi.

\section{Daftar Pustaka}

Dahuri, R., J. Rais, S.P. Ginting, M.J. Sitepu. 1996. Pengelolaan Sumberdaya Pesisir Dan Lautan Secara Terpadu. Jakarta: Pradnya Paramita.

Direktorat Jenderal Pesisir dan PulauPulau Kecil Departemen Kelautan dan Perikanan, 2004. Pedoman Pengelolaan

Ekosistem 
Mangrove. Direktorat Jenderal Pesisir dan Pulau-Pulau Kecil Departemen Kelautan dan Perikanan.

English S. C Wilkinson and V. Baker. 1994. Survey Manual For tropical Marine Resources. Australian Institute of Marine Science, Townsvile.

FAO. 2002. the state of the world fisheries and aqua qulture. FAO, Rome. FAO, 150 pp

Johannes R.E. 1998. Tropical marine reserves should encompass spawning aggregation sites. Parks 8 (2): 53-54.

Kelly S., MacDiarmid A.B., Scott D., \& Babcock R. 2001. The value of a spillover fishery for spiny lobsters around a marine reserve in northern New Zealand. In: Sumaila U.R., Alder J. (eds). Economics of Marine Protected Areas. Papers, Discussions and Issues: A Conference held at the UBC Fisheries Centre July 2000. The Fisheries Centre, University of British Columbia, Vancouver, Canada. p. 99-113.

Magurran. 1988. Ecological diversity and its measurement. New Jersey:Princeton University Press.

McNeely J.A., Thorsell J.W., CeballosLascuráin. 1994. Guidelines:
Development of national parks and protected areas for tourism. 2nd edition. the World Tourism Organization, the United Nations Environment Programme and the World Conservation Union. 53 p.

Myers R.A. and Worm B. 2003. Rapid Worldwide Depletion Of Predatory Fish Communities. Nature 423:280 - 283.

Rodwell L.D., Barbier E.B., Roberts C.M. \& McClanahan T.R. 2001. In: SumailaU.R.,Alder J. (eds). Economics of Marine Protected Areas. Papers, Discussions and Issues: A Conferenceheld at the UBC Fisheries Centre July 2000. Vancouver: The Fisheries Centre, University of British Columbia183-197 p.

Ruitenbeek H.J. 2001. An economic analysis of the spawning aggregation function in Komodo National Park, Indonesia. SPC Live Reef Fish Bulletin 9.

Roberts C.M., Bohnsack J.A., Gell F.,Hawkins J.P. \& Goodridge R. 2001. Effects on marine reserves on adjacent fisheries. Sci 294: 1920-1923.

The National Academies, http://www4.nas.edu/news.nsf/isb n/0309055261? Download, 29 Nopember 2010. 